\title{
E számunk elé
}

Bár nyáron borúsabb hangvételű bevezetőt követte az a - szakmai közvélemény által kedvezően fogadott - tematikus számunk, mely Magyarország 2025 és 2050 horizontján formálódó jövőképének sok szempontú szakmai elemzésével foglalkozott, azonban akkor szólni kellett arról, hogy a júniusban a lap elektronikus rendszerét rosszindulatú támadás érte, mely veszélyeztette a nyitott hozzáférést biztosító portálunkon tárolt anyagokat. Nos, mint arról előző számunk is tanúskodott: „talpra álltunk”, s az idei 5. számmal október végén, s az tervezett második idei angol nyelvű számmal az Opus et Educatio eddigi leggazdagabb évfolyamánál tart. A tervezett korszerúsítést a kényszer felgyorsította, s a változás első szakaszát lezártuk, megvalósult az Open Journal System (OJS) számítógépes rendszerre történő átállása, s a következő fázisban - 2017-től - a kéziratok szerzők által történő feltöltésétől kezdve ebben az új rendszerben fog a szerkesztés megvalósulni. Feltételezhetően ez a lépés sem lesz könnyű, de készülünk rá...

E számunk tematikailag gazdag, tíz tanulmány, projektismertető és recenzió együttese kínál színes és érdekes menüt az olvasóknak. A Tanulmányok rovat fő témája olyan kifejezésekhez kapcsolódik, mint a tehetség, a siker, a szakmai-érzelmi jóllét. Érdemes e témával a történeti párhuzamot, pszichológiai és pedagógiai szempontokat mérlegelve kifejezetten fiatal szerzők (Bognár György, Perger Mónika, Lőrincz Éva Anna) foglalkoznak, ígéretes módon. Stabil és jelentős érdeklődést vált ki a Munkaügyi Szemle rovatunk, melyben most két írás Bagó József és Lovretity Zsigmond tollából kerül közlésre. Bagó József a közfoglalkoztatás intézményi átalakulása legújabb időszakának lényegi összefoglalására vállalkozik. Lovretity Zsigmond tanulmánya arra hívja fel a figyelmet, hogy a demográfiai jellemzők markáns változása - a nagylétszámú korosztályok nyugdíjbamenetele és a várható átlag életkor emelkedése - a munkaerőpiacon drámai változásokat, új és nehezen kielégíthető szükségleteket és életmódunkra is új módon ható megközelítéseket jelez előre az úgynevezett aktív munkatevékenység utáni évekre (post career life).

Eszmélés rovatunkban doktoranduszok és szakvizsgázott gyakorló pedagógusok írásai jelennek meg. Kalmanovits Zoltán a hazai egyházzenei oktatás fejlődését és helyzetét elemzi. Tanulmányának különös érdekességét az adja, hogy a szerző alapkérdése: milyen fejlődésre, továbbhaladási irányra van szükség az egész életen át tartó tanulás jegyében ahhoz, hogy leginkább megközelíthessük elődeink virágzó kulturális életét? Szelezsánné Egyed Dóra írása a pedagógusok körében megjelenő stressz, pszichoterror és kiégés témájáról a gyakorlat szintjén szól. Megfontolandó és elgondolkoztató a szerző gondolata cikke összefoglalójában: „A munkahelyi pszichoterror és a kiégés bevallása még tabunak számít a pedagógustársadalomban." Egy másik, relative új terület pedagógiai kérdéseivel foglalkozik Kas Erika tanulmánya "Távoktatási módszerek alkalmazása a köznevelésben" címmel. Indító idézete: „A Tanítók csak az ajtót nyitják ki, belépned neked kell!” valóban ideillő. Írása rámutat arra, hogy a szakirodalomban sok az illúzió a távoktatással kapcsolatban, amikor ideális diákból és ideális helyzetből indul ki. Megállapítja, hogy a felnőttoktatásban sajnos ez az idealizmus nem érvényesül a köznevelésben. Elemzéséhez probléma érzékenységében kapcsolódik Nagyné Béres Andrea "Hatékony-e a korcsoportos motiváció?" tanulmánya.A gyakorlati pedagógia szempontjait érvényesíti Dobozy Gyöngyi a Kecskeméti Humán Szakképző Iskola 
Kada Elek Közgazdasági Szakgimnázium tanárának elemezése, mely az átlagostól eltérő képességű tanulók iskolai életútjának vizsgálatára vállalkozik. Tanulmánya azért is különösen érdekes, mert ez Opus et Educatio 2. évfolyam 3. számában jelent meg első írása - „A diákok mindennapjai, a tanulói munkaterhek vizsgálata az érettségi előtti és utáni 2-2 évfolyamon" címmmel - melyre pozitív reflexiók érkeztek, s ezek hatására vállalkozott a szerző egy újabb közlemény megjelentetésére.

Projektekről rovatunkban Kraiczi Mária a felsőoktatás megújításában is tevőleges szerepet vállaló TÁMOP-6.1.1-12/1-2013-00011-2013-0001 - Egészségfejlesztési szakmai hálózat létrehozására irányuló projekt felsőoktatási alprojektjének eddigi eredményeit mutatja be. Végül számunk a hagyományoknak megfelelően recenzióval zárul, melyben Koler Kata a kötetet a múlt - jelen - jövő vezérfonalra utalva méltatja igényes szakmaisággal. A kötet a szerkesztő (Kraiczi Mária) eredeti szándékát tekintve az idén 125 . évfordulóját ünneplő Magyar Pedagógiai Társaság felnőttképzéssel foglalkozó kötetének tanulmányait foglalja keretbe. Az igényes összeállítás a történeti vonulat ellenére nem a tudományterület magyarországi történetének bemutatását célozza, hanem három pedagógus generáció szemszögéből mutatja be a hazai andragógia elméletében és a felnőttképzés gyakorlatában azokat a csomópontokat, amelyek az élethosszig tartó tanulás és benne a felnőttképzés elmúlt évtizedeiben bekövetkezett személeti változásait érzékeltetik.

Talán a rövid áttekintés is érzékelteti, hogy valóban színes, számos fiatal szerző által, friss szemléletű írást foglal keretbe jelen számunk. Jó olvasást és további szakmai kezdeményezéseket kívánok, illetve a jövőre vonatkozóan is ígérek.

Budapest, 2016. október

Benedekes András

föszerkesztő 